\title{
Lichens and allied fungi new for Latvia
}

\author{
Rolands Moisejevs \\ Institute of Life Sciences and Technology, Daugavpils University, Parādes 1a, Daugavpils, Latvia, LV-5401. \\ E-mail: rolands.moisejevs@biology.lv
}

\begin{abstract}
Six lichenized fungi (Calicium parvum, C. trabinellum, Carbonicola anthracophila, C. myrmecina, Peltigera extenuata, Pycnora sorophora), two lichenicolous (Clypeococcum hypocenomycis and Illosporium carneum), and two saprobic calicioid fungi (Chaenothecopsis savonica and Microcalicium arenarium) are reported as new for Latvia.
\end{abstract}

Keywords: Latvia; lichenicolous; calicioid; saprobic fungi

\section{INTRODUCTION}

Several essential contributions for Latvian lichen biota have been presented recently (Ābolina et al., 2015; Jurciņš et al., 2014; Moisejevs, 2015; Motiejūnaitè et al., 2016). These contributions added over one hundred species of lichens and allied fungi to the Latvian checklist, including re-find of Lobaria amplissima, a species which was considered to be extinct in the country. Currently about 690 species of lichenized and allied fungi are recorded in Latvia. This paper further supplements the knowledge on lichens and allied fungi in Latvia.

\section{MATERIAL AND METHODS}

All referred specimens were collected by the author in 2015-2016 in different regions of Latvia, during local inventories of protected habitats, according to Latvian interpretation of Annex I EU Habitat Directive in (Auniņš et al., 2013). The collections were determined using the routine lichenological methods (Smith et al., 2009). Specimens were examined under stereomicroscope Nikon SMZ 800. Water mounted hand-made cross sections were examined under light transmission microscope Nikon Eclipse E100. The nomenclature of taxa mainly follows Nordin et al. (2011). Doubtful specimens were compared with the collections at the herbarium of the Institute of Botany, Nature Research Centre, Vilnius (BILAS). For each specimen the protected habitat type and number according to Annex I EU Habitat Directive is added in brackets, if relevant. Species distribution data in neighboring countries (for Russia only Pskov region) are provided. All reference specimens are deposited at the Herbarium of Daugavpils
University, Institute of Life Sciences and Technology, Laboratory of Botany (DAU).

In the species list non-lichenized saprobic fungi are marked with + and lichenicolous fungi with \#.

\section{THE SPECIES}

CALICIUm Parvum Tibell - Krāslavas County, Kaplavas District, about 250-300 m off Šilovkas

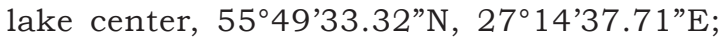
in dry old-growth Pinus sylvestris forest site, burned in past (evaluated as 9010* Western Taiga), on Pinus sylvestris bark; 24 August 2016 (DAU 5018009001).

Note. The species is known in Belarus (A. Tsurykau pers. comm.), Estonia (Lõhmus, 1998) and Lithuania (Motiejūnaité, 1999).

Calicium trabinellum (Ach.) Ach. - Krāslavas Co., Ūdrīšu District, Tartaks village, about $600 \mathrm{~m}$ E off Tartaks village, $55^{\circ} 52^{\prime} 54.454^{\prime \prime} \mathrm{N}$, 265'35.746" $\mathrm{E}$; in boggy Pinus sylvestris forest site with Ledum palustre L. (evaluated as 91D0* Bog woodland), on wood of pine snag; 10 September 2015; DAU518008001; Daugavpils Co., Dvietes District., Kinkausku forest area, $56^{\circ} 8^{\prime} 30.884^{\prime \prime} \mathrm{N}, 26^{\circ} 14^{\prime} 28.676^{\prime \prime} \mathrm{E}$; in young dry Pinus sylvestris forest, on wood of pine stump; 12 July 2016; DAU518008002.

Note. Known in Belarus (Golubkov \& Titov, 1990), Estonia (Lõhmus, 1998), Lithuania (Motiejūnaite, 1999) and Russia (Istomina \& Likhacheva, 2014). In Lithuania C. trabinellum is treated as an indicator species of undisturbed boggy pine forests (Motiejūnaitè et al., 2004). 
Carbonicola anthracophila (Nyl.) Bendiksby \& Timdal - Gulbenes Co., Stradu District, highway P36, turn to Lazdaga and Kaḷna lakes, about 200-300 $\mathrm{m}$ from the highway,

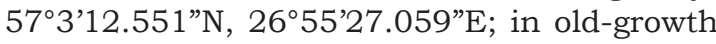
dry Pinus sylvestris forests (evaluated as 9010* Western taiga), on Pinus sylvestis bark; 2 August 2015; DAU552001001; Krāslavas Co., Kaplavas District, Šilovkas lake, about 250-300 m from Šilovka lake central part, $55^{\circ} 49^{\prime} 33.32$ "N $27^{\circ} 14^{\prime} 37.71^{\prime \prime} \mathrm{E}$; in old-growth dry Pinus sylvestris forests (evaluated as 9010* Western taiga), on Pinus sylvestis bark; 24 August 2016; DAU552001002; Alūksnes Co., Liepnas District, about $2 \mathrm{~km}$ to SE from Liepna

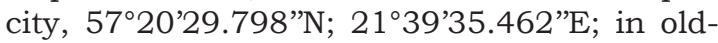
growth moistured Pinus sylvestris forest, on burned pine snag, on wood; 26 September 2016; DAU552001003.

Note. The species is known in Belarus (Yatsyna, 2012), Estonia (Randlane et al., 1999) and Lithuania (Motiejūnaite, 1999). In all neighboring countries, the species is mainly found in old-growth, previously burned forest sites. In Latvia, in all cases the lichen was found in dry old-growth pine stands impacted by past forest fires.

Carbonicola myrmecina (Ach.) Bendiksby \& Timdal - Alūksnes Co., Liepnas District, about

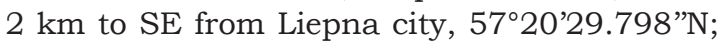
$21^{\circ} 39^{\prime} 35.462$ 'E; in old-growth moistured Pinus sylvestris forest, on burned pine snag, on wood; 26 September 2016; DAU552002001.

Note. Known in Estonia (Randlane et al., 1999) and Lithuania (Motiejūnaite, 1999).

+Chaenothecopsis savonica (Räsänen) Tibell Ventspils Co., Užavas District, Užava town, Nature Preserve Užava, about $600 \mathrm{~m}$ SE off Užava lighthouse, $57^{\circ} 12^{\prime} 17.798$ 'N, $21^{\circ} 25^{\prime} 37.462$ 'E; in old-growth birch-spruce-pine forest site (evaluated as 9010* Western taiga), on Picea abies snag; 10 September 2015; DAU527005001.

Note. C. savonica is known in Estonia (Lõhmus, 1998) and Lithuania (Motiejūnaitè, 1999).

\#Clypeococcum hypocenomycis D. Hawksw. Krāslavas Co., Ūdrīšu District, Borovka village, about $300 \mathrm{~m} \mathrm{~N}$ off the farmstead "Ciemati", $55^{\circ} 55^{\prime} 9.289^{\prime \prime} \mathrm{N}, 2^{\circ} 59^{\prime} 23.060^{\prime \prime} \mathrm{E}$; in a middleaged Pinus sylvestis forest stand, on thalli of
Hypocenomyce scalaris growing on Pinus sylvestris; 14 September 2015; DAU646001001; Krustpils Co., Atašienes District, About 700 m $S$ off Teiču Nature Reserve observation tower, 56 31'28.203"N, 2634'2.132”E; in boggy P. sylvestris forest with Ledum palustre L., (evaluated as 91D0* Bog woodland), on thalli of Hypocenomyce scalaris growing on Pinus sylvestris; 17 March 2016; DAU646001002.

Note. It is a common lichenicolous fungus, known in Belarus (Tsurykau \& Khramchankova, 2011), Estonia (Randlane et al., 2015) and Lithuania (Motiejūnaité, 1999).

\#Illosporium CARneum Fr. - Krustpils Co., Atašienes District, about 500 m NE off Teiču Nature reserve observation tower, $56^{\circ} 32^{\prime} 54.332^{\prime \prime} \mathrm{N}$, $26^{\circ} 25^{\prime} 25.403^{\prime \prime} \mathrm{E}$; on the railroad earthwork, on thalli of Peltigera extenuata growing on soil (it was in the state of an anamorph); 26 April 2016; DAU647001001.

Note. Illosporium carneum is one of the commonest peltigericolous fungi, it is known in Estonia (Suija, 2005) and Lithuania (Motiejūnaite, 1999).

+Microcalicium arenarium (Hampe ex A.Massal.) Tibell - Ventspils Co, Užavas District, Užava town, Užava Nature Reserve, about $700 \mathrm{~m}$ SE off Užava lighthouse, $57^{\circ} 11^{\prime} 7.195^{\prime \prime} \mathrm{N}$, $21^{\circ} 25^{\prime} 16.528$ " E; in old-growth birch-sprucepine forest site (evaluated as 9010* Western taiga), on a sand layer in Picea abies root plate; 10 Sept 2015; DAU643003001.

Note. Known in Belarus (Golubkov, 1987), Estonia (Lõhmus, 1998) and Lithuania (Motiejūnaitè et al., 2013). In all neighboring countries the species is known only from very few localities. In Estonia it has been assessed as vulnerable (Lõhmus \& Lõhmus, 2011). In Lithuania the species was known from literature data and only recently was recorded in one locality (Motiejūnaite et al., 2013). In Belarus the species is known from a single locality, Belovezhskaya Pushcha National Park, and is considered as very rare (Golubkov, 1987). Regional distribution and sparce occurrence of $M$. arenarium is a good basis to include it to local red lists.

Peltigera extenuata (Vainio) Lojka - Krustpils Co., Atašienes District, about $500 \mathrm{~m} \mathrm{NE}$ off Teiču Nature Reserve observation tower, 
$56^{\circ} 32$ '54.332"N, $26^{\circ} 25^{\prime} 25.403$ " E; on the railroad earthwork, on soil; 26 April 2016; DAU647001001.

Note. The species is recorded in all neighboring countries (Randlane et al., 2015; Motiejūnaite, 1999).

PYCNORA SOROPHORA (Vain.) Hafellner - Krustpils Co., Atašienes District, Nature preserve "Great Pelečāre bog", about $300 \mathrm{~m}$ to NW from "Bernāni" farmstead, $56^{\circ} 28^{\prime} 22.8^{\prime \prime} \mathrm{N} 26^{\circ} 34^{\prime} 04.9^{\prime \prime} \mathrm{E}$; in boggy Pinus sylvestris forest with Ledum palustre L. (evaluated as 91D0* Bog woodland), on bark of Pinus sylvestris; 25 June 2016; DAU 648001001; Ventspils Co., Kolkas District., Slitere National Park, about $300 \mathrm{~m}$ to $\mathrm{S}$ from Kolka Cape, 5745'11.73”N 22 35'56.62”E; in dry Pinus sylvestris forest (evaluated as 2180 Wooded dunes of the Atlantic, Continental and Boreal region), on bark of Pinus sylvestris; 24 July 2016; DAU 648001002.

Note. The species is known in Belarus (Tsurykau et al., 2012), Estonia (Randlane et al., 2015) and Lithuania (Motiejūnaitè, 1999).

\section{ACKNOWLEDGEMENTS}

Author is grateful to Dr. Jurga Motiejūnaite (Nature Research Centre, Vilnius) for shared experience, helpful advices and checking determination of doubtful specimens. Gulnara Tagirdzhanova (St. Petersburg State University), Irina Stepanchikova (St. Petersburg State University \& Komarov Botanical Institute, Russian Academy of Sciences) and Andrei Tsurykau (Gomel State University) are thanked for sharing known information on species distribution in Russia (Pskov region) and Belarus. Also, Mr. Māris Nitcis (Daugavpils University) is thanked for technical support in field and in cameral work.

\section{REFERENCES}

Ābolina, A., Piterāns, A. \& Bambe, B. 2015. Lichens and bryophytes in Latvia. Checklist. DU AA "Saule". Salaspils. 213 pp.

Aunin̦š, A., Lārmanis, V., Rove, I., Rūsin̦a, S., Laime, B. (eds). 2013. European Union Protected Habitats in Latvia. Interpretation Manual. Riga, Latvian Fund for Nature, Ministry of Environmental Protection and Regional Development. 320 pp.
Golubkov, V.V. 1987. Species composition and structure of lichen flora of the State Hunt Reserve "Belovezhskaya Pushcha". Part 1. Species composition of lichen flora of Belovezhskaya Pushcha (An annotated list). Proceedings of the Academy of Sciences of the BSSR Series of Biological Sciences 6: 91-92 pp. (In Russian).

Golubkov, V. V. \& Titov, A. N. 1990. Lichenes Caliciales RSS Belorussiae. Novitates Systematicae Plantarum Non Vascularum 27: 97-101. (In Russian).

Istomina, N. B. \& Likhacheva, O. V. 2014. Lichens of National Park „Sebezsky”. The second international conference "Lichenology in Russia: problems and perspectives". Programme and proceedings of the international conference dedicated to the 300th anniversary of the Komarov Botanical Institute RAS and the 100th anniversary of the Institute of Cryptogamic Plants.(In Russian). Saint Petersburg. 263 pp.

Lõhmus, P. 1998. List of Estonian calicioid lichens and fungi. Folia Cryptogamica Estonica 32: 43-46.

Lõhmus, A. \& Lõhmus, P. 2011. Old-forest species: the importance of specific substrata vs. stand continuity in the case of calicioid fungi. Silva Fennica 45(5): 1015-1039. https://doi.org/10.14214/ sf. 84

Jurciņš, D., Mežaka, A., Strazdina, L., Gerra-Inohosa, L., Perševica, G. \& Piterāns, A. 2014. Refound of extinct lichen Lobaria amplissima (Scop.) Forssell in Latvia. Acta Biologica Universitatis Daugavpiliensis 14(1): 59-65.

Moisejevs, R. 2015. Some new to Latvia lichens and allied fungi. Acta Biologica Universitatis Daugavpiliensis 15(2): 285-292.

Motiejūnaitè, J. 1999. Checklist of lichens and allied fungi of Lithuania. Botanica Lithuanica 5(3): 251-269.

Motiejūnaitė, J., Czyżewska, K. \& Cieśliński, S. 2004. Lichens - indicators of old-growth forests in biocentres of Lithuania and North-East Poland. Botanica Lithuanica 10(1): 59-74.

Motiejūnaitè, J., Chesnokov, S.V., Czarnota, P., Gagarina, L.V., Frolov, I., Himelbrant, D., Konoreva, L. A., Kubiak, D., Kukwa, M., Moisejevs, R., Stepanchikova, I., Suija, A., Tagirdzhanova, G., Thell, A. \& Tsurykau, A. 2016. Ninety-one species of lichens and allied fungi new to Latvia with a list of additional records from Kurzeme. Herzogia 29(1): 143-163. https://doi.org/10.13158/ heia.29.1.2016.143

Motiejūnaitè, J., Kukwa, M., Lõhmus, P., Markovskaja, S., Oset, M., Prigodina-Lukošienè, I., Stončius, D. Uselienè, A. 2013. Contribution to the Lithuanian flora of lichens and allied fungi. IV. Botanica Lithuanica 19(1): 3-7. https://doi.org/10.2478/ botlit-2013-0001

Nordin, A., Moberg, R., Tønsberg, T., Vitikainen, O., Dalsätt, Å., Myrdal, M., Snitting, D. \& Ekman, S. 2011. Santesson's Checklist of Fennoscandian 
Lichen-forming and Lichenicolous Fungi. Ver. April 29, 2011. http://130.238.83.220/santesson/ home.php

Randlane, T. \& Saag, A. (eds). 1999. Second checklist of lichenized, lichenicolous and allied fungi of Estonia. Folia Cryptogamica Estonica 35: 1-132.

Randlane, T., Saag, A. \& Suija, A. 2015. Lichenized, lichenicolous and allied fungi of Estonia. Ver. December 31, 2015. http://esamba.bo.bg.ut.ee/ checklist/est/home.php

Smith, C. W., Aptroot, A., Coppins, B. J., Fletcher, A., Gilbert, O. L., James, P. W. \& Wolseley, P. A. (eds). 2009. The lichens of Great Britain and Ireland. British Lichen Society, London, UK. 1046 pp.

Suija, A. 2005. Lichenicolous fungi in Estonia II: Basidiomycota and conidial fungi. Nova Hedwigia 80(34): 349-365. https://doi.org/10.1127/0029$5035 / 2005 / 0080-0349$
Tsurykau, A. \& Khramchankova, V. 2011. Lichens from Gomel region: a provisional checklist. Botanica Lithuanica 17(4): 157-163.

Tsurykau, A., Khramchankova, V. \& Motiejūnaite, J. 2012: Pycnora sorophora (Lecanoraceae) - lichen species new to Belarus. Botanica Lithuanica 18 (1): 80-82. https://doi.org/10.2478/v10279012-0010-x

Yatsyna, A. P. 2012. Note about lichens of Glussk district. In: Sharukho, I. N., Pirozhkina, I. I. \& Barinova, I. N. (eds). Problems of sustainable development of the Republic of Belarus and neighboring countries. Abstracts of the Second International Conference. Mogilev State University Press, Mogilev. Pp. 316-319. (In Russian). 